TEATP

UDC 792.03

\title{
The Formation of the Visual Theatre Aesthetics: Theater Practice and Experiments of the Russian Avant-garde in the 1900-1930s
}

\author{
M. A. Spasskaia
}

Russian State Institute of Performing Arts, 34, Mokhovaya str., St. Petersburg, 191028, Russian Federation

For citation: Spasskaia, Margarita. "The Formation of the Visual Theatre Aesthetics: Theater Practice and Experiments of the Russian Avant-garde in 1900-1930s". Vestnik of Saint Petersburg University. Arts 8, no. 4 (2018): 593-604. https://doi.org/10.21638/spbu15.2018.404

The visual theater is now rapidly developing on the Russian stage. In such performances the director, like an artist creates visibly embodied poetic images in the theater space and uses an actor as an element of the stage composition. The works of "visualists" - R. Wilson, R. Castellucci, J.Nadj, D. Krymov, "Engineering Theater AKHE", etc. - clearly demonstrate one of the defining trends of contemporary theatre: the transfer of effective activity from the verbal component to the visual elements. However, despite the seeming novelty of techniques, the ideas developed by modern directors in the visual theatre often turn out to be high-tech, but quite logical continuation of theatre and artistic avant-garde experiments of the 1900-1930s. That was the time when artists and directors began to explore intensively each other's possibilities and started to move towards each other. In the article the development of approaches to work with visual imagery as a sense-making element of the performance is explored on the example of performances staged by V. Meyerhold, A. Tairov, E. G. Craig ("Hamlet" in the Moscow Art Theatre, 1909-1911) etc. On the example of theoretical works and scenic experiments of V. Kandinsky, K. Malevich, V. Tatlin etc., it is studied how the Russian avant-garde started to bring under theatrical techniques. The author analyzes the process of mutual influence between the theater and fine arts at the beginning of the 20th century and establishes parallels between experiments of the 1900-1930s and the main aesthetic conventions of modern visual theater.

Keywords: visual theater, visual arts, avant-garde, futurism, performance art, V. Meyerhold, V. Kandinsky, K. Malevich.

In the past few decades, more and more performances have appeared on the Russian stage labelled as the "visual theater", "visual image theater", "artist's theater", etc. These definitions give rise a rather wide range of associations. Theater is visual by its nature,

(c) Санкт-Петербургский государственный университет, 2018 
which means that any performance can be described in this way. However, the definition "visual theater" and such like are used, often intuitively, when talking about the work of a certain group of ensembles. One of the most important features of such performances is the marked shift of focus from the actor playing the role to the visual elements and the visual images that appear on the stage, which become so vividly active that it turns out possible to base on them almost the entire figurative system and sometimes the action itself.

The character of the structural features of visual performances is associated with their "hybrid" nature. This trend formed as a result of the convergence of scenic and visual arts, the interest of the stage director and artist to each other's instruments. As a result, for a director who creates "before our eyes pictures and objects from improvised materials including human bodies,$-<\ldots>$ actors can perform an auxiliary function or exist alongside the image" [1, p. 222], while the actor's main task is not to represent the character, but to participate in the formation of the stage composition.

Many features typical of modern theatre in general can be illustrated by the example of visual productions - the works of R. Wilson, R. Kastellucci, J. Naja, D. Krymov, "AKHE Engineering Theater", V. Koleichuk, etc. In particular, they clearly demonstrate one of the main trends - the growing role of visual elements of the performance in the process of sense-making, the transfer of the effective activity from the verbal component to the visual component. In addition, the visual theater is "genetically" connected with the performance art that arose as a result of the artists' interest in the potential of the "acting person", and often vividly illustrates how the "performative turn", rapidly changing the theatrical landscape, offers new ways of communication between the actor, role, viewer and space.

However, until relatively recently, the experiments of "visualist" filmmakers on the Russian stage remained mostly outside the scope of theatrical studies. The main impulse, which brought out visual theater from this semi-marginal state, was festival performances that provided opportunities for presenting European and Russian "experimental" productions to the public. So, for example, the work of R. Wilson was shown for the first time in Russia within the "Chekhov's International Theater Festival" in 1998. In 2003, the nomination for the "Golden Mask" award in the "Novation" nomination largely helped to gain a foothold for one of the brightest representatives of the visual theater on the Russian stage - the "AKHE Engineering Theater", already quite famous abroad. Theater critic D. Goder wrote: "When at the festival of the best Russian performances $<\ldots>$ rail-tracks were laid in a Lenexpo pavilion for 'Sine loco', and on them a platform with rows of chairs and a hundred spectators in them started to move, stopping in front of encrypted scenes of ancient myths, $\langle\ldots\rangle$ the audience and theatre professionals realized how broad and varied the art of the stage was. Before, the creators of the 'AKHE' Maxim Isaev and Pavlo Semchenko had not been considered directors and actors, and had been called merely artists. In 2003, everything changed and they received a major theater prize" [2].

However, despite the fact that visual theater is often described as an "experimental" and "innovative" movement, such an approach to creating a performance is not something entirely new. The work of "visualists" is often a high-tech, but quite logical and expected continuation of ideas that arose in the Russian theater in the first quarter of the 20th century. It was at this time, which became a period of most rapid development in art, that the powerful technological progress, the new philosophical concepts, the increased 
interest in Oriental cultures, the new psychological and psychiatric teachings and many other factors changed the human worldview, the perception of and communication with the reality. "Our beautiful world has become even more beautiful - now there is speed in it" [3, p. 160], wrote F. Marinetti in his manifesto. Speed and dynamics gradually became a "new religion of life". Images, impressions and sensations were layered on each other. The image of the surrounding reality became increasingly more complex and compound. The laws of the aesthetic reality changed alongside.

The interpenetration of art forms, which began at the turn of the 20th century, and the subsequent destruction of the obvious boundaries between art and reality became some of the most significant changes in the artistic life of the last century and radically changed the approach to theatrical practice. A new milestone in the theatrical history the assertion of the main role of the director - determined a new approach to the creation of a theatrical work. Stage direction that understood performance as an integral composition naturally absorbed the compositional laws of fine arts, music, dance. This led to a more active and diversified use of their elements in performances.

In addition, the period when stage direction emerged and obtained its form happened to be the time of a once again aggravated confrontation between realistic and unrealistic concepts in art. It goes without saying that the director's theater joined this struggle and has been bearing the traces of those battles to this day.

The first steps towards a digression from the concept of realistic theater, life-likeness, illustrativeness and the plot as the main effective components of the performance at the turn of the 20th century were undertaken by West European symbolists who maintained that "the objective world either does not exist at all or is not accessible to human perception, as a human being deals only with a complex of sensations, concepts, ideas, which he creates in himself, and this complex has nothing in common with the outlying being" [4, p. 86]. They saw the task of art not in depicting reality, but in "making it possible to feel the essential reality without naming it" [5, p.58].

The strivings of symbolist theatre in Europe went in different directions. "The artist's theatre", where the most important element was the visual image of the play (in contrast, for example, to "the poet's theater"), was only one of them. However, the general character of all the strivings was the same. In the centre of the narrative was a symbol, an artistic image, which could not be fully formulated. The most important components of the performance were the spectator's imagination and sensual perception. The desire to emphasize the foreign reality of the stage world and the semantic role of the subtext led to the need to focus on the image system. Despite the fact that representatives of the Russian Symbolist movement made significant adjustments to the West European model, the fundamental aesthetic attitudes remained unchanged.

Symbolist theories were applied in the work of V.E. Meyerhold. In his productions, the artistic composition, the musical organization, and the rhythmic system became essential for the theatre. The imagery of the performance grew out of the entire complex of expressive means. As far as the symbolist aesthetics is concerned, one of the main methodological ideas of the director was stylization, with which "the idea of convention, generalization and symbol is inextricably linked" [6, p. 109]. Characteristically, at first, 
Meyerhold understood stylization only visually. The production of "Gedda Gabler" may serve as an example of this approach (Theater at Officers, 1907, artist N. N. Sapunov), where the main principle of space organization was a "wall painting". With the help of the costumes designed by V.D. Milioti based on the colour combination of all the stage elements the actor became part of the larger image. At the same time, the performers' faces, which made the impression of pictorial masks, plasticity and speech, stylized in accordance with the situation, created "a single rhythmic field of the conventional construction" in the play [7, p. 52].

Later on, proceeding to the development of his concept of conventional theatre, Meyerhold, on the one hand, no longer organized the space in terms of pictorial principles in a straightforward manner, but on the other hand, he developed the formerly outlined principle with regard to the existence of the actor, a principle opposite to that of experiencing the role. The word, which became "not a strong enough tool to reveal inner dialogue" [6, p. 135], was replaced with plastic movement. It was the pattern of the actors' movements, which formed the mise en scene, that helped the spectator not only to observe the development of the plot, but also to delve into the subtext (much later the director remarked: "Mise en scene helps reveal the subtext, that what lies between the lines" $[8$, p. 308$])$.

The conventional technique of Meyerhold was in opposition to the "illusionary methods" of life-likeness on the stage. The mask as a generalization through the schematization of the image that Meyerhold introduced into the Russian scene as opposed to the character, the theatre's own language developed by him, where "words are only patterns on the canvas of movements" [8, p. 212], undoubtedly, became an important step in the development of visual imagery as a sense-making principle of the play.

A considerable contribution to the further development of scenography was made by theatrical constructivism, which absorbed and reinvented the ideas of the modernist and avant-garde trends that had preceded it. The ideas of functional set design, implemented by constructivists, influenced later, in the second half of the 20th century, the development of effective set design. The principles of the latter, in turn, contributed in many ways to the formation of the visual theatre aesthetics.

It is important to note here that constructivism's effective functionality was applied not only to the stage space, but also to the principles of director's design, and acting technique. It was the actors' acting out the objectless object that made its figurative content appear. The method of performer's existence on the stage was most vividly manifested in Meyerhold's biomechanics. "The apparatus for the acting" predetermined the rigor of the acting. "The accidental movement of the actor was eliminated - the design immediately revealed any clumsiness and highlighted any plastic ignorance, but also graphically emphasized the richness and beauty of a meaningful and refined movement" [9, p. 207]. Meyerhold defined the actor's technique in the constructivist theater as the "creativity of plastic forms in space" [8, p.488], shifting the emphasis from the word and imitation to discovering a new semantic potential of the body and gesture.

The penetration of cinema methods into the theatre world can be traced through Meyerhold's productions. As early as at the beginning of the $20^{\text {th }}$ century, the directors had mastered technical novelties that influenced the spectacular component of the performance: strong lighting devices, screen, projection, etc. However, what is more important to us is that the "cinefication of the theatre" contributed to the emergence of new, 
setting techniques in designing the composition of action, the disintegration of "a single dramatic act in a series of sharply changing episodes" [10, p.4]. Also, the adoption of cinematic techniques opened the possibility for "interpreting theatrical scenery as a cinematic frame" [10, p.4]. Adr. Piotrovsky, citing Meyerhold's production of "The Inspector-General", wrote: "Playing on an artificially reduced site. - Are not the laws of designing cinematographic mise-en-scenes, limited by the frame and the screen, seen here? The planning of the actors' groups on a huge stage tablet, which can not entirely be seen by the viewer's eye, is traditional; it comes from the classical era of the formation of the European theatre. The cinema broke sharply with this tradition, it developed new laws of the subtlest and at the same time the most complicated composition of people and things on the narrow square of the frame. This rearranges and turns upside down all the principles of setting mise en scenes. $<\ldots>$ (In the "Inspector". - M. S.), the transition from a reduced site to the use of the entire volume of the scene (bribery episode) is the most interesting example of the "transition from a close-up to a general plan" in theatre context. It is logical to assume that the penetration of cinematographic techniques into the territory of the stage influenced the actor and required him to master the "technique of cinematic acting" [10, p. 4].

The director's theatre was approaching the idea of viewing the play as a dynamic spatial system in which the expressiveness of the actor is based on plasticity interacting with the scenography in a number of ways. But the initial settings in most cases turned out to be same. One of them, along with the interest in finding new options for the actor to deal with his role, was the need to revise the concept of the performance space. The decorators who painted the landscape backdrops, which then travelled from one production to another, were replaced by the artists who developed the design together with the director, in the same stylistic key and inseparable connection with the director's concept.

The idea of creating a scenography that could become an important and self-sufficient sense-making element of the play can be seen even in the relatively early productions of the Art Theater, the decorations of V.E. Egorov and N.P. Ulyanov ("The Life of Man", "The Drama of Life", 1907). But, of course, a radical revision of the theatrical scenery, the design that could not only carry independent artistic meaning, but also interact with the actor, occurred in 1911. It was then that G. Craig offered in "Hamlet" several ideas that became innovative for the world theatre.

The use of movable screens provided the possibility "to make the free, associative connection of scenes and individual episodes of the play visible" [11, p. 161] with the help of the backdrop setting, and the image of Elsinore, manifested in a gigantic living "body", created by a golden mantle that fell from the shoulders of the king and queen and covered the crowd of courtiers, clearly demonstrated the possibility of a plastic unification of the living and the inanimate on the stage.

Along with Meyerhold and the Art Theater, other directors developed approaches that advanced visual imagery, the dominance of non-verbal over word and descriptiveness, the use of decorative design as a way of expressing the emotional state of the characters and the atmosphere. Among them were A. Ya. Tairov, S. M. Eisenstein, N. P. Akimov, I. G. Terentyev, G. I. Gidoni, to name but a few. Their work formed the approaches where the distance between the visible and verbal expression, the importance of visual imagery as a sense-making element of the performance increased significantly, and the stage elements acquired the qualities of a character. 
The interest of the stage director and the artist to studying each other's instruments was mutual. At the beginning of the 20th century, painting asserted itself in discovering new points of view, a new way of seeing, new approaches to the creation and perception of a work of art. The representatives of the movements that are typically labelled as the avant-garde in art criticism were ones of the first to sense the wind of change, and the new strategies of interacting with the audience were shaped in their experiments - the approaches aimed at searching for "higher sensitivity" and based on emotional, synaesthetic perception of art, creating a work as an open artistically active object, the meaning and content of which were not complete without direct participation by a particular viewer. Customary tools and possibilities, limited by distinct definitions of genres and forms, were not sufficient for the avant-garde to put new ideas into life. Classically fixed boundaries were blurred, new ways of artistic expression appeared, combining techniques of various forms. If earlier painting, sculpture and architecture had clear specific boundaries, they became less and less distinguishable in the experiments of the early 20th century. Like in Europe, the scenic experiments of Russian "new artists" were made in line with searching for the transition "from easel forms to counter-reliefs, structures, objects, installations, environmental activities and further to the action art" [12, p.11].

In addition, the development of new technical means to produce images, cameras and photo cameras, on the one hand, expanded the range of possibilities, but on the other, pushed the artists to look for new means of self-identification and to develop methods of purely artistic expression.

The theatrical stage became one of the possibilities for the avant-garde, firstly, to move from images painted on a plane to three-dimensional space, and secondly, to master the fourth dimension - time - following the image on the film and to start working with moving objects.

So, the early attempts, still on the plane, the collages of the 1910s, in which various materials and objects were connected, were followed by the transition to creating objects outside the canvas. Even the first futuristic "plastic complexes" united "the plastic, chromatic, architectural sensations, the sense of movement, noise and smell in a single allo" $[13$, p. 34]. By the way, the Futurists were the first to talk about the possibility to express sound by visual means. Thus, for example, they introduced the graphic-verbal form in "free pictures" (tavole parolibere), "compositions from "free words" [14, p. 33] that "reveal the very matter of the language as it is, accentuate its visual form, transmitting a new futuristic lyricism based on 'condensed metaphors', 'telegraphic images', 'sums of vibrations', 'dye balances', etc. <...> They turn into a special kind of visual signs, in which the very shape of the letter and the visual graphics of the word that do not depend on the meaning, play a leading role" [14, p.33]. "Free pictures" became a vivid manifestation of where the overwhelming majority of the avant-garde was moving to: the non-verbal replaced the verbal in art, the verbal sign acquiring a graphic embodiment and dven becoming material. The desemantization of the word led to the semantization of the image.

Futurism developed its own concept of theatre, which implied the departure from psychology and illustrativeness on the stage. The purpose of art, according to the Futurists, was not "psychological photographs", "historical reconstructions", or imitation, but 
"an intoxicating synthesis of life in its numerous and typical lines" [3, p. 159], in which man was subordinated to the dynamics and speed of the mechanized world.

According to one of the main representatives of Russian futurism, V. Mayakovsky, theatre, which transmitted a photographic image of reality, fettered all of its creators, the playwright, the artist, and the actor. In the "theatre of the future" created by the Futurists, actors "will be able to create unexpected dynamic effects, which until now have been neglected ... because of the old prejudice that urges to imitate and show reality" [15, p. 379]. E.Prampolini wrote in the Manifesto of Futuristic Scenography that the stage should henceforth serve as "not a pictorial background, but an electromechanical neutral architecture" within which it will be possible to realize a performance where "the intonation even of a word with no meaning and fictional yet rhythmycally free movements of the human body express the greatest inner experiences" [13, p.48]. Kinetic objects in the space of the stage were, according to the futurists, to be in motion and, together with the use of noise and sounds, to increase the living tension of action, to maximize the decorative, object, light and other visual means of expressiveness.

Marinetti's followers, like most representatives of the artistic avant-garde, considered ballet the most acceptable form for a person's existence on the stage. In studying the possibilities of bodily expressiveness and tactile sensations, futurism, and the artistic avant-garde in general, saw, among other things, the possibility of freedom from the dogma of the verbal and descriptive art. However, in his manifesto "The Futuristic Dance" the father of Futurism noted that it was necessary "to overcome muscle capabilities and strive to approach dance in the ideal of the motor-enhanced body, which we have been dreaming about for so long" [op. on: 16, p. 29]. However, the problem of actor was not primary for the Futurists. It is no accident that they often replaced a live performer with an object or a puppet. However, it should be noted that in the Russian Futurist tradition, unlike the European one, the desire to displace the human actor from the scene was not so strong [5, p. 129]. Numerous manifestos repeated that the main goal was to merge the performer and the visual design into a single plastic complex, and "sound, scene and gesture should create psychological synchronism in the spectator's soul” [13, p. 139].

In the opinion of V.I. Berezkin, one of the few researchers of "the artist's theatкy", V. V. Kandinsky was the first in Russian art to pose the question of new approaches to using scenic expressiveness. In the article "About the Scenic Composition" (the almanac "The Blue Horseman", 1912), the artist claimed that the fundamental structural principle for achieving a visual composition that developed in stage time and space should be the synthesis of color, sound and movement ("musical movement, color movement and dance movement" [17, p. 101]). According to Kandinsky this synthesis called "the new ballet" could accommodate the dynamic painting. Drama theatre, where form is created by "an external event and the external coherence of action" [17, p.93], and painting is used on the stage as a decoration (not an essential element, but external decoration), could put this idea into practice.

It is also important to note that a year before the article was written, the artist published the book titled "On Spiritual Art". In it he expounded his theory of color semantics, which underlies the impact of the dynamic painting and turns out to be significant as to the sense-making role of painting in a stage statement. According to Kandinsky, the departure from descriptiveness towards abstraction and form exploration opened vistas for discovering a "higher sensuality", the synaesthetic perception of art. 
The production of the stage composition "The Yellow Sound", which was supposed to be a manifestation of Kandinsky's ideas, was not implemented because of the outbreak of the First World War (although the artist's ideas were partly embodied in the visual version of the ballet "Pictures at an Exhibition" by M. P. Mussorgsky in 1928 in Desau). However, in his projects one can find ideas that anticipated the development of visual theater in the second half of the 20th century - the development of ways to create an atmosphere with the help of light and colour in space, the sound component in a close connection with visual images, and the use of abstract painting laws on the stage, and much more.

Ideas resonating with Kandinsky's theories were embodied in the production of the opera "Victory over the Sun" by M.V.Matyushin, A.E. Kruchenykh and K. S. Malevich ("The world's first futurist theatre", 1913). The appearance of a work by a poet, a musician and an artist on the stage per se was a definitive step for the Russian visual theatre.

Malevich created images of characters, dressing actors in masks and costumes in the form of figures made up of geometric shapes. As Berezkin concludes, Malevich endowed the mask and costume with such expressiveness that they, strongly influencing the viewer, "became independent visual-plastic characters" [18, p.151]. In other words, it was not the costume and mask that helped the actor's play, but the performer had to submit to the "figurative-plastic character", to carry out a set of actions for him. B. K. Lifshits recalled: "What Malevich did in the 'Victory over the Sun' could not fail to impress spectators who ceased to feel like listeners from the moment when the black depths of the 'sozert$\operatorname{sog}^{\text {'1 }}$ (hall) opened before them. $<\ldots>$ From the primeval night, the tentacles of spotlights snatched parts of one or another object, and, saturating it with colour, filled it with life. $<\ldots>$ The novelty and originality of Malevich's methods consisted primarily in the use of light as an element, creating a form that legitimizes the being of a thing in space. For the first time principles established in painting since Impressionism were transferred to the sphere of three dimensions. <...> Painting stereometry was for the first time born within the stage box, a strict system of volumes was established, minimizing the elements of randomness imposed on it from outside by the movements of human figures. Most of these figures were shredded with the blades of the spotlights, alternately losing their hands, feet, heads, as for Malevich they were geometrical bodies that were not only to decompose into components, but to totally dissolve in a the space of a painting, as well. The only reality was the abstract form that absorbed in itself all the Luciferic fuss of the world without a trace" [19, p. 386].

Thus, the main function of the actor was to perform a set of actions that helped to form the moving picture, a dynamic painting within the stage. This fact allows us to say that the production of the "Victory over the Sun", despite the chosen theatrical form, goes beyond the limits of the traditional theatre model, since in this case both the actor and the role in the usual sense were absent.

The set design also pursued unconventional goals. Each of the compositions on the backdrop had to express the essence of the picture through a rhythmic combination of abstract forms with signs of reality (the circle of the sun, a wheel, a clock, etc.). In M. Etkind's opinion, by juxtaposing compositions the artist conveyed "the complication of structure, the amplification of the atmosphere of unrest and anxiety, the activation of the plastic movement" [cf. to: 18, p. 152]. The approach to the creation of the "Victory over the Sun"

\footnotetext{
1 A neologism made of two words meaning: "contemplate" and "hall".
} 
clearly demonstrated the importance of "the internal regularity of a work of art, perceived primarily as its composition" in the artists" work on production [19, p. 387].

The ideas of Kandinsky and Malevich were developed and supplemented in other avant-garde experiments: El' Lisitsky's "electromechanical performances" and "figurines", N. I. Kogan's "Suprematist Ballet" projects, P. F. Chelishchev's surreal ballet, etc.

The ideas of futurism, cubism, geometric abstractionism were reinvented by constructivism, where the focus was on design and functionality. Despite different approaches to understanding this movement, researchers recognize that it continues the tradition of the earlier avant-gardists: the rejection of psychologism and emotionality in favour of form, simplicity and clarity of geometric proportions, clarity of constructive decisions, strict logic and rationality.

In comprehending the space, volume and structure, the constructivist artists also did not ignore the possibilities of the theatrical stage. The example of V.E. Tatlin's production of V. Khlebnikov's dramatic poem "Zangezi" (Petrograd Museum of Art Culture, 1923) is of special interest for this study.

The poster said: "cars, people, searchlights" participate in the play [12, p. 18]. The goal of the experiment was to find a visual embodiment for the poem. In his work on the visual image the artist assumed that "Khlebnikov takes sound as the main element. <...> To reveal the nature of these sounds, surfaces diverse in terms of material and processing,are used" [12, p.27]. Additionally, of importance were the light and sound design. On the stage, sharp rays of light formed a focused beam, a "cone-shaped cliff", on top of which was the main character who pronounced the words "of the song of the stellar language". Tatlin explained the use of this technique by the need to "manage the attention of the audience, $\langle\ldots\rangle$ introducing order and consistency" [12, p. 28]. At the bottom of the "cliff" the choir listened to him. Paper scrolls went down the cable, whose text was loudly recited by the chorus, articulating in a special way, emphasizing rhythm and tone. Individual letters, transcription of sounds and algebraic-phonetic formulas appeared on the stage on special tables.

At the same time, it is important to note that, no matter how theatrical the artists' performances may seem, these statements did not always become theatrical. For the artistic avant-garde the stage became only one of the many ways for implementing their ideas, and primarily was of interest to artists as a space for creating a "four-dimensional picture", while the problem of working with the performer, for instance, proved to be secondary, and in general rarely was of signifance.

However, concerning the artist's work with the performer in the context of the emergence and development of visual theatre aesthetics, there is another point that can not be avoided.

At the beginning of the $20^{\text {th }}$ century, it was the avant-garde experiments that formed new ways of making an impact, based on modeling the situation where the subject and the object of creativity cease to fulfill their direct purpose. While the classical rhetoric implies "the use of aesthetic methods for extra-aesthetic purposes, the new rhetoric is the creation of quasi-esthetic objects and quasi-esthetic situations" [21, p. 15]. Thus, the Dadaists tried to introduce the object of reality into the artistic environment, and the futurists to introduce the artistic object into reality. Despite the fact that the new ways of expressiveness were studied along the line that separated the physical world and aesthetic world, it did not abolish the boundary between them, but on the contrary "constantly 
pointed to its presence, that allowed to borrow elements of reality, while remaining within the space traditionally occupied by art" [22, p. 11]. But, in the opinion of the researchers (R. Goldberg, A. Obukhova, V.Zolotukhin, etc. [see: 16; 22; 23; 25]), it was the processes that took place in the avant-garde art in the first three decades of the twentieth century that created favourable conditions for the emergence of performative forms that finally eliminated these boundaries.

In Russia and abroad, N.N.Evreinov was one of the first to formulate a theoretical approach to extend the laws of art to reality. In his writings, as early as the beginning of the $20^{\text {th }}$ century, he in fact predetermined a performative turn, defining it as theatricalization of life.

The first action art experiments in the Russian culture took place in 1910 in the work of Futurists and Imagists. For instance, the artist M. Larionov, proclaiming that "it's time for art to invade life", and that "face painting is the beginning of an invasion", painted faces to himself and his comrades, and thus turning into living art objects, went for a "futuristic walk" around Moscow. But such avant-garde experiments in the first third of the $20^{\text {th }}$ century were a style of behavior intended to shock the public. They remained strictly an aesthetic gesture. Nevertheless, the attention of the avant-garde to the body, movement and gesture in the creation of a new artistic language caused a radical change in art in the second half of the $20^{\text {th }}$ century and led to new forms of expressiveness - performance art, in which "the artist's body replaced the usual media" [23, p. 31].

In the early Soviet era, attempts to change the system of means of impact, to make the spectator the subject of the action, were also made in the theatre. In particular, new mechanisms for building relations with the viewer were developed in mass performances ("To the World Commune", "Taking the Winter Palace", etc.). At this stage in the development of Russian art, the separation of the object from thaw environment still remained, but such experiments can be called the first attempts to form a performance as a performative event with the help of new ways of interaction between the viewer and the performer.

However, the search that began in the first decades of the $20^{\text {th }}$ century in Russian art, was almost completely interrupted in the mid-30s and resumed only towards the late 1960s. At this time a new step in the development of fine art and scenography, the gradual penetration of performance art into the national culture, resumed the convergence of the director and the artist. And it was the ideas of the early $20^{\text {th }}$ century, reinterpreted and supplemented by new discoveries and opportunities, that became the impulse that formed the "new" trend - the visual theater.

The $20^{\text {th }}$ century set before the art the task to study the infinitely diverse ways of interaction and perception. By the beginning of the $21^{\text {st }}$ century, the "author-spectator" relations had radically changed. The author had long been unwilling to be a dictator and organizer of the process of sense-making. His goal is to offer the "rules of the game", to launch reflection, to become an "access point" to the meanings that the viewer finds and forms independently. Responding to this challenge, the visual theater becomes the space in which a new type of theatrical text is formed, becomes the form of the stage work, which is more accustomed not to the category of action but to the category of state, and the main thing is not the logic of the narrative, but the formation of a wide field of interpretation through the influence of visual image system and monitoring the process of its creation and development. 
While the traditional drama theater, as it was noted by H.-T.Lehmann [24] is a story-theatre, a plot-theatre in which the author guides the viewer through the maze in a pre-compiled route, nd while the modern theatre is increasingly a game-theatre, in which there are many variants of the route, scattered fragments of different texture with which the viewer interacts himself and collects them, as he pleases, the visual theater turns out to be probably one of the most striking examples of this game. And although its strategies might only provisionally be called new, they must surely be called vital.

\section{References}

1. Goder, Dina. Khudozhniki, vizionery, tsirkachi. Ocherki vizual'nogo teatra. Moscow: Novoe literaturnoe obozrenie, 2012. (In Russian)

2. Goder, Dina. “Triumf uzlovatykh verevok". Luchshii iz mirov, 2003. Accessed April 11, 2018. http:// theatretimes.ru/triumf-uzlovatykh-verevok. (In Russian)

3. Andreyev, Leonid, ed. Nazyvat' veshchi svoimi imenami. Programmnye vystupleniia masterov zapadno-yevropeyskoy literatury XX veka. Moscow: Progress, 1986. (In Russian)

4. Bychkov, Viktor. Estetika. Uchebnik. $2^{\text {nd }}$ ed. Moscow: Gardariki, 2004. (In Russian)

5. Maksimov, Vadim. Modernistskie kontseptsii teatra ot simvolizma do futurizma. Tragicheskie formy $v$ teatre XX veka. Uchebnoe posobie. St. Petersburg: SPbGATI, 2014. (In Russian)

6. Meierkhol'd, Vsevolod. "K istorii i tekhnike teatra". In Meierkhol'd, Vsevolod. Stat'i. Pis'ma. Rechi. Besedy, compiled, edited and commented by Aleksandr Fevral'skii, 105-43. 2 parts. Moscow: Iskusstvo, 1968, pt. 1. (In Russian)

7. Titova, Galina. Meierkhol'd i Komissarzhevskaia. Modern na puti $k$ Uslovnomu teatru. Uchebnoe posobie. St. Petersburg: SPbGATI, 2006. (In Russian)

8. Meierkhol'd, Vsevolod. Stat'i. Pis'ma. Rechi. Besedy. Compiled, edited and commented by Aleksandr Fevral'skii. 2 parts. Moscow: Iskusstvo, 1968, pt. 2. (In Russian)

9. Titova, Galina. Tvorcheskii teatr i teatral'nyi konstruktivizm. St. Petersburg: SAbGATI, 1995. (In Russian)

10. Piotrovskii, Adrian. “Kinofikatsiia teatra”. Zhizn' iskusstva, no. 47 (1927): 4. (In Russian)

11. Bachelis, Tat'iana. Shekspir i Kreg. Moscow: Nauka, 1983. (In Russian)

12. Berezkin, Viktor. Teatr khudozhnika. Rossiia. Germaniia. Moscow: Agraf, 2007. (In Russian)

13. Lazareva, Ekaterina, comp., transl., comment. Vtoroi futurizm. Manifesty i programmy ital'ianskogo futurizma: 1915-1933. Moscow: Gileia, 2013. (In Russian)

14. Bobrinskaia, Ekaterina. Futurizm. Moscow: Galart, 2000. (In Russian)

15. Maiakovskii, Vladimir. "Teatr, kinematograf, futurizm”. In Maiakovskii, Vladimir. Teatr i kino, compiled, edited and commented by Aleksandr Fevral'skii, 379-81. 2 vols. Moscow: Iskusstvo, 1954, vol. 2. (In Russian)

16. Goldberg, Rouzli. Iskusstvo performansa. Ot futurizma do nashikh dnei [Performance Art. From Futurism to the Present]. Translated by Anna Aslanian. Moscow: Ad Marginem Press et al., 2013. (In Russian)

17. Stakhorskoi, Sergei, comp., ed., comment. Iz istorii sovetskoi nauki o teatre. 20-e gody. Moscow: GITIS, 1988. (In Russian)

18. Berezkin, Viktor. Iskusstvo stsenografii mirovogo teatra. Teatr khudozhnika. Istoki i nachala. $3^{\text {rd }}$ ed. 12 vols. Moscow: Librokom, 2012, vol. 4. (In Russian)

19. Livshits, Benedikt. Polutoraglazyi strelets. Compiled by Ekaterina Livshits and Pavel Nerler. Leningrad: Sovetskii pisatel', 1989. (In Russian)

20. Tarabukin, Nikolai. Ot mol'berta k mashine. Moscow: Rabotnik prosveshcheniia, 1923. (In Russian)

21. Rudnev, Vadim. Entsiklopedicheskii slovar' kul'tury XX veka. Kliuchevye poniatiia i teksty. $2^{\text {nd }}$ ed. Moscow: Agraf, 2003. (In Russian)

22. Obukhova, Aleksandra, ed. Performans v Rossii. 1910-2010. Kartografiia istorii. Moscow: MSI "Garazh", 2014. (In Russian)

23. Taylor, Brandon. The Art Today. London: Calman\&Kind LTD, 2005.

24. Leman, Khans-Tis. Postdramaticheskii teatr [Postdramatic Theatre]. Translated and commented by Natal'ia Isaeva. Moscow: ABCdesign, 2013. (In Russian) 
25. Kostelanetz, Richard. "The Theatre of Mixed-Means Medium". In Theatre of mixed-means: an introduction to happenings, kinetic environments, and other mixed-means presentation, edited by Richard Kostelanetz, 3-42. London: Pitman, 1968.

Received: May 5, 2018

Accepted: August 30, 2018

Author's information:

Margarita A. Spasskaia — postgraduate; Margarita.spasskaia@gmail.com

\section{Формирование эстетики визуального спектакля:} театр и эксперименты русского художественного авангарда 1900-1930-х годов

\section{A. Спасская}

Российский государственный институт сценических искусств, Российская Федерация, 191028, Санкт-Петербург, ул. Моховая, 34

Для цитирования: Spasskaia, Margarita. “The Formation of the Visual Theatre Aesthetics: Theater Practice and Experiments of the Russian Avant-garde in 1900-1930s". Вестник Санкт-Петербургского университета. Искусствоведение 8, no. 4 (2018): 593-604. https://doi.org/10.21638/ spbu15.2018.404

Визуальный театр на русской сцене сегодня является одним из наиболее стремительно развивающихся направлений. Сценический текст таких постановок формирует зримо воплощаемые поэтические образы, которые режиссер, подобно художнику, создает в театральном пространстве. Главной задачей актера оказывается не репрезентация персонажа, а участие в формировании сценической композиции. Работы «визуальщиков» - Р. Уилсона, Р. Кастеллуччи, Ж. Наджа, Д. Крымова, «Инженерного театра АХЕ» и др. - отчетливо демонстрируют одну из определяющих тенденций современного сценического искусства: перенос действенной активности с вербальной составляющей на визуальную. Однако, несмотря на кажущуюся новизну приемов, идеи, разрабатываемые современными режиссерами, оказываются часто высокотехнологичным, но всегда вполне логичным, закономерным продолжением экспериментов театрального и художественного авангарда 1900-1930-х гг. Именно тогда художник и режиссер начали движение навстречу друг другу. В статье исследуются подходы к работе с визуальной образностью как смыслообразующим элементом спектакля, реализовывавшиеся в русском театре в постановках В.Э. Мейерхольда, А. Я. Таирова, Г. Крэга («Гамлет» в Художественном театре, 1909-1911 гг.) и др. На примере теоретических разработок и сценических экспериментов В. В. Кандинского, К. С. Малевича, В. Е. Татлина и др. проиллюстрировано, каким образом русский художественный авангард осваивал инструментарий сценических форм. Анализируется процесс взаимовлияния театра и изобразительного искусства в начале XX века, проводятся параллели между поисками 19001930-х гг. и основными эстетическими установками современного визуального театра. Ключевые слова: визуальный театр, театр художника, художественный авангард, футуризм, перформанс-арт, В.Э. Мейерхольд, В.В. Кандинский, К. С. Малевич.

Контактная информация:

Спасская Маргарита Андреевна - аспирант; Margarita.spasskaia@gmail.com 